\title{
New Regional Editor for India: Professor Amitabha Chattopadhyay
}

\author{
Chris D. Geddes
}

Published online: 13 February 2009

(C) Springer Science + Business Media, LLC 2009

With the significant growth in the Journal of Fluorescence over the last few years, I have both created and invited for, several regional Journal editor positions. Last year I was most pleased to announce that Professor Martin Hof and Professor Trevor Smith had joined the Journal of Fluorescence as the regional editors for both Europe and Australasia, respectively. It now gives me great pleasure to announce that Professor Amitabha Chattopadhyay has agreed to serve as the regional editor for India, a region of the world wellrecognized for its outstanding contributions to Fluorescence Spectroscopy and indeed Spectroscopy as a whole.

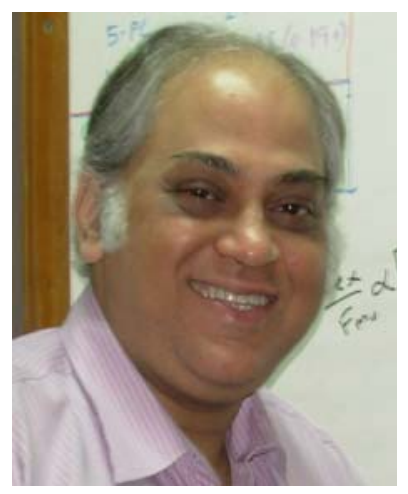

Professor Amitabha Chattopadhyay obtained his B.Sc. with Honors in Chemistry from St. Xavier's College in Calcutta and M.Sc. from the Indian Institute of Technology at Kanpur. He received his Ph.D. from the State University of New York at Stony Brook, USA. In his Ph.D. research, he developed a convenient and sensitive method, known as

C. D. Geddes $(\bowtie)$

The Journal of Fluorescence, The Institute of Fluorescence, Baltimore, MD, USA

e-mail: geddes@umbi.umd.edu the parallax method, to determine membrane penetration depths of a wide variety of membrane-bound fluorophores including proteins and peptides. The parallax method for analysis of membrane penetration depth became very popular in subsequent years. He carried out his postdoctoral work at the University of California, Davis, CA, USA, during 1987-1989. In his postdoctoral work, he worked on lipid-protein interactions in the nicotinic acetylcholine receptor from Torpedo californica. He subsequently joined the Center for Cellular and Molecular Biology, Hyderabad (India), in 1989, and is presently Deputy Director at the center. Prof. Chattopadhyay's work is focused on monitoring organization, dynamics and function of biological membranes in healthy and diseased conditions. His group has developed and applied novel, innovative and sensitive techniques (such as the wavelength-selective fluorescence approach) using fluorescence spectroscopy for monitoring solvent relaxation in membranes, membrane-mimetic media, and proteins. These pioneering studies have led to a better understanding of the dynamics of hydration of membranes and proteins. Prof. Chattopadhyay's group has made pioneering contribution on the role of membrane lipids in regulating the function of G-protein coupled receptors such as the $\operatorname{serotonin}_{1 \mathrm{~A}}$ receptor. He has used fluorescence-based microscopic approaches such as FRAP and FCS to provide novel insight into dynamics and function of membranebound receptors.

Professor Chattopadhyay has also been instrumental in designing and teaching courses related to biomembranes and fluorescence spectroscopy for advanced students in India and other parts of the world. Professor Chattopadhyay is an elected fellow of all the Indian academies of science. He was awarded the prestigious Shanti Swarup Bhatnagar Award, Ranbaxy Research Award, and currently is a J.C. Bose Fellow. $\mathrm{He}$ serves on the editorial boards of several international 
journals as well. Armed with over three decades of fluorescence spectroscopy experience, Professor Chattopadhyay is well-equipped for this new role. Subsequently, please join me in welcoming Professor Chattopadhyay to the role of Regional Editor for India.
Finally, I thank our authors, reviewers, editorial board and regional editors for their continued support of the Journal of Fluorescence, thank you.

January 14th 2009.

http://theinstituteoffluorescence.com/ 